\title{
Three decades of reference evapotranspiration estimates for a tropical watershed in the eastern Amazon
}

\author{
RENATO O. DA SILVA JÚNIOR ${ }^{1,2}$, EVERALDO B. DE SOUZA ${ }^{1,2}$, ALEXANDRA L. TAVARES ${ }^{2}$, JOSÉ A. \\ MOTA $^{2}$, DOUGLAS B.S. FERREIRA ${ }^{1,2}$, PEDRO W.M. SOUZA-FILHO ${ }^{2,3}$ and EDSON J.P. DA ROCHA ${ }^{1}$ \\ ${ }^{1}$ Programa de Pós-Graduação em Ciências Ambientais, Universidade Federal do Pará, Instituto \\ Geociências, Av. Augusto Correa, 1 Guamá, 66075-110 Belém, PA, Brazil \\ ${ }^{2}$ Instituto Tecnológico Vale, Rua Boaventura da Silva, 955, Nazaré, 66055-090 Belém, PA, Brazil \\ ${ }^{3}$ Programa de Pós-Graduação em Geologia e Geoquímica, Universidade Federal do Pará, \\ Instituto Geociências, Av. Augusto Correa, 1 Guamá, 66075-110 Belém, PA, Brazil
}

Manuscript received on March 6, 2017; accepted for publication on August 16, 2017

\begin{abstract}
This study estimated the reference evapotranspiration rate (ETo) for the Itacaiúnas River Watershed (IRW), Eastern Amazonia, and measured the accuracy of eight empirical equations: Penman-Monteith (PM), Priestley-Taylor (PT), Hargreaves and Samani (HS), Camargo (CAM), Thornthwaite (TH), Hamon (HM), Kharrufa (KF) and Turc (TC) using monthly data from 1980 to 2013. In addition, it verifies the regional applicability to the IRW using a for the Marabá-PA station. The methods TC and PM (FAO56) presented the best results, which demonstrate that radiation and higher temperatures are the dominant drivers in the Evapotranspiration process, while relative humidity and wind speed have a much smaller impact. The temporal and spatial variability of ETo for IRW show has strong seasonality, increasing during the dry season and decreasing during the rainy season. The statistical analyses at $1 \%$ level of significance, indicates that there is no correlation of the residuals between the dry and rainy seasons, and test of the physical parameters such as mean temperature, solar radiation and relative air humidity explains the variations of ETo.
\end{abstract}

Key words: calibration, decades, eastern Amazon, evapotranspiration, methods, watershed.

\section{INTRODUCTION}

The hydrological cycle represents the continuous movement of water on the Earth under the action of gravity and solar energy. Evaluating the terms that make up the water balance equation, especially evapotranspiration (ET), involves the survey of observed data or the development of expressions

Correspondence to: Renato Oliveira da Silva Júnior

E-mail: renato.silva.junior@itv.org that represent the transport mechanism of water volumes. The reference evapotranspiration (ETo) represents the process of water loss to the atmosphere, considering a standard grassy surface covering the soil, with no humidity restriction. ETo is controlled by the energy balance, the atmospheric demand, and the supply of water from the soil to plants (Pereira et al. 1997). Xu and Singh (2001, 2002) divide the methods of estimating ETo into five different categories based on (i) water balance, 
(ii) mass transfer, (iii) combined methods, (iv) radiation, and (v) air temperature.

Various studies worldwide have demonstrated that the Penman-Monteith method (PM-FAO56) is quite accurate (Xu and Chen 2005, Yoder et al. 2005, López-Urrea et al. 2006, Jabloun and Sahli 2008, Barros et al. 2009, Carvalho et al. 2011, Xavier et al. 2015, Caporusso and Rolim 2015). This model has been validated in relation to the data measured by lysimeters under various climatic conditions. For this reason, it has been considered the best method to estimate ETo and is widely used as a standard for comparison with other empirical methods (Allen et al. 2005, 1998, ASCE-EWRI 2005, Berti et al. 2014, Djaman et al. 2015, Dehghani Sanij et al. 2004, Ghamarnia et al. 2015, Itenfisu et al. 2003, Jain et al. 2008, Lima et al. 2013, Pandey et al. 2014, Pereira et al. 2015, Tabari et al. 2013, Widmoser 2009, Mohan and Arumugam 1996, Xu et al. 2013). Empirical or deterministic models with a physical basis, with or without random or probabilistic components, are used to calculate ETo (Soares et al. 2003, Borges and Mendiondo 2007).

Nandagiri and Kovoor (2006) evaluated the performance of seven different empirical methods for the determination of ETo under different climatic conditions in India, and they reported that the empirical equation of Turc is the best option under humid conditions. Tabari et al. (2013) compared 31 different ETo equations, including two new radiometric equations they developed (similar to the work of Irmak et al. 2003) in the north of Iran (in a humid environment), considering the PM-FAO56 equation as the standard. The results revealed that the developed equation performed better than the other equations selected. Thus, the radiation-based models were the most appropriate options for estimating ETo. Carvalho et al. (2011), in turn, argued that some studies are variants of the PM-FAO method, seeking better fits for certain regions (Temesgen et al. 2005, Allen et al. 2006, Gavilán et al. 2007, 2008).

In Brazil, many studies have tested the accuracy of different models for determining ETo. In in the North region (Boa Vista - Roraima), using a monthly scale, the best results were obtained with the Blaney-Criddle (BC) method (Caporusso and Rolim 2015). In the Center-West region \{Aquidauana - Mato Grosso, Oliveira et al. (2011)\} obtained results with acceptable accuracy using the methods of Hargreaves and Samani (HS) and Camargo (CAM). In the South region (Santa Maria - Rio Grande do Sul), Medeiros (1998) concluded that on a daily scale, the methods of Penmam (PEN), Camargo (CAM), and Tanner and Pelton provide the best results. In the Southeast region (Mantiqueira mountain range - Minas Gerais), Pereira et al. (2009) concluded that the Haise, Penmam (PEN), Solar Radiation (SR), and BlaneyCriddle (BC) methods had the best accuracy. The differences among the ETo values estimated by the various methods in different regions of Brazil lie in the characteristics and specificities of the regional climate, as demonstrated by Camargo and Camargo (2000) after an analysis of some methods used to calculate ETo for different regions of São Paulo state.

Most Brazilian watersheds lack hydrometeorological monitoring stations suitable for obtaining reliable data that enable accurate estimates of evapotranspiration and, consequently, water availability. Unfortunately, this scenario is more pronounced in the Amazon region. The search for alternative solutions is essential, given the limited number of instruments in operation and the lack of historical data. Thus, the objectives of this study are to i) estimate the reference evapotranspiration (ETo) for the Itacaiúnas River Watershed (IRW), located in the eastern Amazon; ii) assess the accuracy of the following eight empirical equations, using mean monthly data for 1980-2013: PenmanMonteith (PM) - which was recommended by the 
FAO (Allen et al. 1998) - Priestley-Taylor (PT), Hargreaves and Samani (HS), Camargo (CAM), Thornthwaite (TH), Hamon (HM), Kharrufa (KF), and Turc (TC); and iii) test the regional applicability to the IRW, calibrating the selected methods using a data series (1980-2013) from the Marabá (Pará) station.

\section{MATERIALS AND METHODS}

\section{STUDY SITE}

The IRW is located in the Tocantins-Araguaia hydrographic region (Brasil 2003), situated approximately $600 \mathrm{~km}$ south of the equator, draining an area of approximately $42,000 \mathrm{~km}^{2}$ (Figure 1). The Carajás plateau is a prominent feature in the landscape of the area, whose altitude ranges from 600 to $900 \mathrm{~m}$, which contrasts with the adjacent areas with altitudes ranging from 80 to $300 \mathrm{~m}$. In the area of the basin, originally two types of land cover predominate - tropical rainforest and mountain savannah - but, at present, the land use is dominated by extensive pastures that surround a mosaic of forest remnants. The latter occupy indigenous lands and other protected conservation areas, which occupy cover 11,700 $\mathrm{km}^{2}$, or approximately a quarter of the area of the basin (Souza-Filho et al. 2016). The climate in the region is typical monsoon (Am) (Alvares et al. 2014). In the region, the rainy season (November to May) and dry season (June to October) are well defined - the rates for the total annual rainfall can vary between 1,800 and $2,300 \mathrm{~mm}$ during the rainy season and from less than $10 \mathrm{~mm}$ to a maximum of $350 \mathrm{~mm}$ during the dry season (Moraes et al. 2005, Silva Júnior et al. in press).

\section{ENERGY BALANCE}

Surface radioactive processes can influence significantly the distribution of moisture and heat between soil and atmosphere, thus affecting the behavior of the weather, the climate, and the Earth's biosphere (Bastiaanssen et al. 1998, Roerink et al. 2000). The energy exchanges in the soil-vegetationatmosphere interface, which occur via the net radiation ( $\mathrm{Rn})$ and heat flux soil $(\mathrm{G})$, sensible $(\mathrm{H})$, and latent (LE) \} components, are essential for climate and hydrological modeling (Machado et al. 2014). The latent heat flux (LE), which represents the loss of water from the surface in the form of vapor, can be converted into evapotranspiration (ET) in units of mm.day ${ }^{-1}$, which is an essential component for calculating the water balance. In turn, the term "LE", in units of W.m. ${ }^{-2}$, is used in studies of the energy balance (EB) of the Earth's surface and includes all the major sources of energy (Rn) and energy consumption (ET, G, and H). The LE is obtained as a residual from the classical surface energy balance equation (Liu 2007):

$$
E T=R n-G-H
$$

in which $\mathrm{Rn}$ is the net radiation, $\mathrm{H}$ is the sensible heat flux density, and $\mathrm{G}$ is the heat flux density in the soil, all in $\mathrm{W} \mathrm{m}^{-2}$.

The determination of the energy balance on the Earth's surface involves two parts: the first consists of quantifying the net energy (Rn) of the fluxes of the shortwave and longwave radiation received and emitted by the surface, and the second part involves estimating the fluxes $(\mathrm{G}, \mathrm{H}$, and LE) from utilization of the net radiation available on the Earth's surface (Liu 2007, Machado et al. 2014). The ETo can be quantified directly through lysimeter measurements or can be calculated indirectly using the energy balance approach (empirical models). The direct measurements using lysimeters are time consuming and require precise instrumentation. The indirect approach used in this work is based on meteorological data available at terrestrial stations.

DATA ACQUISITION AND METHODS FOR ESTIMATING ETO

Six variables were used to determine the reference evapotranspiration (ETo): maximum air 


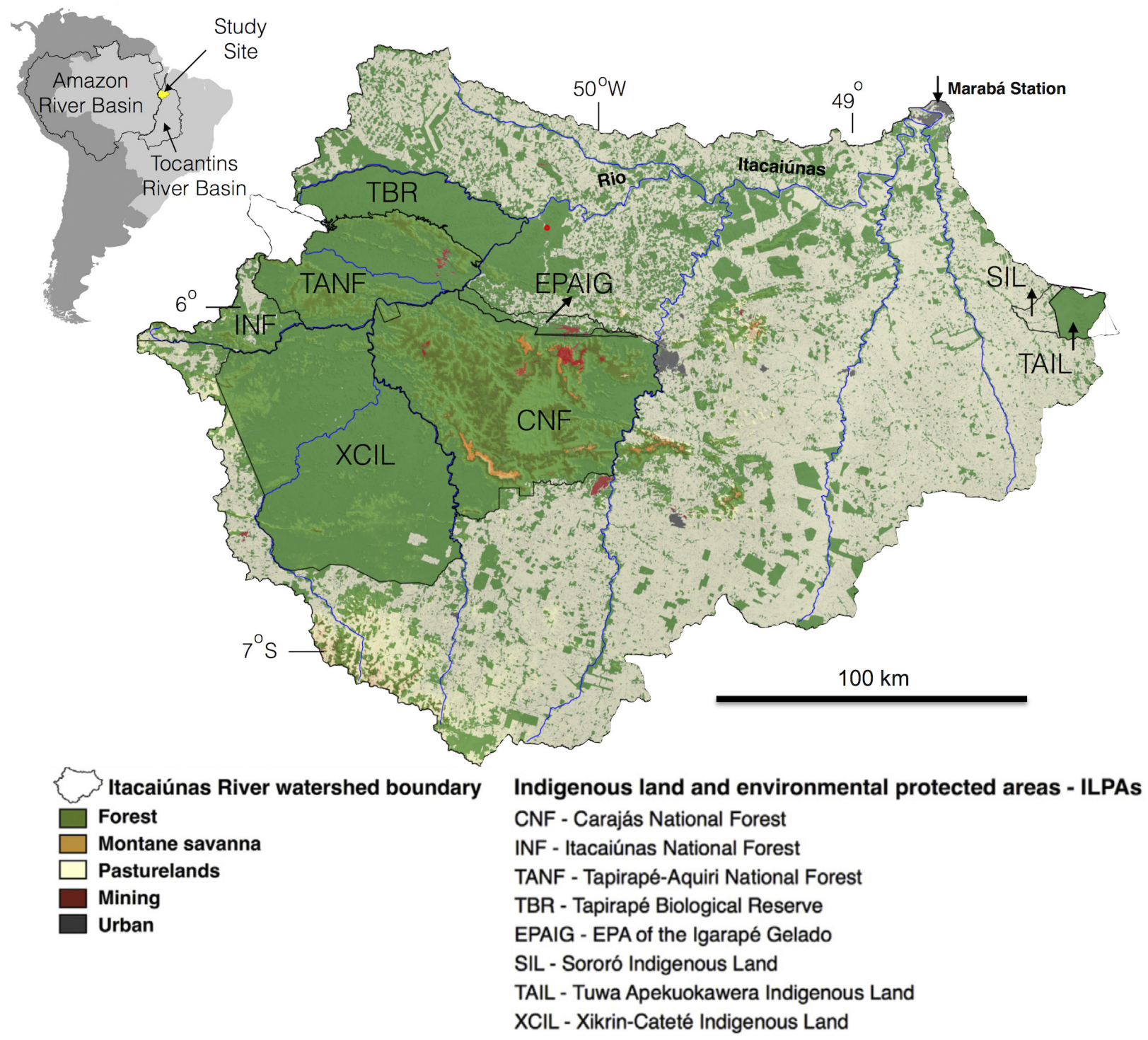

Figure 1 - Location map of the Itacaiúnas River Watershed (IRW), showing the contrast in vegetation between protected areas and areas dominated by pastures (modified from Souza-Filho et al. 2016).

temperature $\left(\mathrm{T}_{\max },{ }^{\circ} \mathrm{C}\right)$, minimum air temperature $\left(\mathrm{T}_{\min },{ }^{\circ} \mathrm{C}\right)$, mean air temperature $\left(\mathrm{T}_{\text {mean }},{ }^{\circ} \mathrm{C}\right)$, wind velocity $\left(\mathrm{u}_{2}, \mathrm{~m} . \mathrm{s}^{-1}\right)$ at a height of $2 \mathrm{~m}$, solar radiation $\left(\mathrm{Rs}, \mathrm{MJ} . \mathrm{m}^{-2}\right)$, and relative air humidity (RH, \%). These data were extracted using the Grid Analysis and Display System (GrADS) software and were based on the grid-interpolated dataset from Xavier et al. (2015), which used the daily observation data of 3,625 conventional and/or automatic weather stations installed in the major Brazilian watersheds (for the period between January 1,
1980 and December 31, 2013) belonging to the Brazilian Meteorology Institute (Instituto Nacional de Meteorologia - INMET), the Brazilian Water Agency (Agência Nacional de Águas - ANA), and the São Paulo Department of Water and Electrical Energy (Departamento de Águas e Energia Elétrica de São Paulo - DAEE). The ETos were calculated using the methods described in Table I.

To validate the regional applicability of this study, the daily records for the period between $01 / 01 / 1980$ and $12 / 31 / 2013$ of the Meteorological 
Database for Education and Research (Banco de Dados Meteorológicos para Ensino e Pesquisa - BDMEP) provided by INMET for the Marabá station - located in the extreme northeast of the IRW (latitude of $05^{\circ} 21^{\prime} 36^{\prime \prime} \mathrm{S}$, longitude of $49^{\circ}$ 07 ' $48^{\prime \prime} \mathrm{W}$, and altitude of $95 \mathrm{~m}$ ) — were used. The «solar radiation» variable was estimated from insolation values via the empirical equation described in Allen et al. (1998). The albedo used for this station was obtained via the weighted mean of the albedo values used in the literature (Allen et al. 1998) for areas of pasture (0.23).

\section{STATISTICAL TESTS}

Statistical tests were performed for the physical parameters mean temperature $\left(\mathrm{T}_{\text {mean }}\right)$, solar radiation $\left(\mathrm{R}_{\mathrm{s}}\right)$, relative air humidity $(\mathrm{RH})$, and wind velocity $\left(\mathrm{V}_{\mathrm{w}}\right)$ to assess the level of contribution of each of these parameters to the estimation of the reference evapotranspiration (ETo). Subsequently, several methods were tested in order to define the method that best represents the behavior of the ETo in the IRW. This was done considering that the energy exchanges in the soil-vegetationatmosphere interface are determining factors in the behavior of the mentioned physical parameters and that they differ significantly during the rainy and dry seasons in the basin.

Significance tests were applied via the Ordinary Least Squares (OLS) method, Student's $\mathrm{t}$-test $(\mathrm{t})$, and other special tests such as the adjusted coefficient of determination $\left(\mathrm{R}^{2}\right)$, standard error of estimate (Se), Fisher's F-test (F), KolmogorovSmirnov test of normality (KS), and DurbinWatson autocorrelation test (DW). It is important to note that the performance classification for model selection was based on the statistical results of the estimates of all of these tests. Thus, the best fitting model was chosen considering that the estimated model satisfies all the estimates. The correlation between the values estimated by the standard method and the values estimated by the other models was analyzed using the software SPSS v. 21.

\section{SUMMARY OF PREVIOUS WORKS}

Using the Surface Energy Balance Algorithm for Land (SEBAL) for the Caxiuanã National Forest in the eastern portion of the Amazon, Ferreira Junior et al. (2013) obtained results consistent with the values reported for the region (Souza Filho et al. 2005, Sousa et al. 2007), showing that the highest evapotranspiration values occur between June and December, especially during the dry season. In accordance with Negrón Juárez et al. (2007), the ET range at various points in the Amazon is $2.5 \pm 0.4$ to $4.1 \pm 0.4 \mathrm{~mm} . \mathrm{d}^{-1}$ in the rainy season and $3.8 \pm 0.6$ to $4.3 \pm 0.9 \mathrm{~mm}^{-\mathrm{d}^{-1}}$ in the dry season. Additionally, when investigating the temporal and spatial variability of ET, using the eddy flux measurements from eight different towers of the Large-Scale Biosphere-Atmosphere Experiment in Amazonia (LBA), Hasler and Avissar (2007) concluded that the evapotranspiration in stations close to the equator $\left(2-3^{\circ} \mathrm{S}\right)$ has strong seasonality, increasing during the dry season and decreasing during the rainy season.

Various studies have shown that the surface radiation balance is primarily responsible for ET (Ferreira Junior et al. 2013). In the dry season, the ET is more influenced by the amount of moisture stored in the soil during the previous rainy season than by rainfall events during the dry season. Furthermore, during the dry season, the stored soil moisture available for absorption by roots may be sufficient to keep the ET rate equal to or even greater than that during the rainy season (Shuttleworth 1988, Nepstad et al. 1994, Malhi et al. 2002, Sommer et al. 2002, Souza Filho et al. 2005, Negrón Juárez et al. 2007, Von Randow et al. 2011). Thus this suggest that in the dry season, 
RENATO O. DA SILVA JÚNIOR et al.

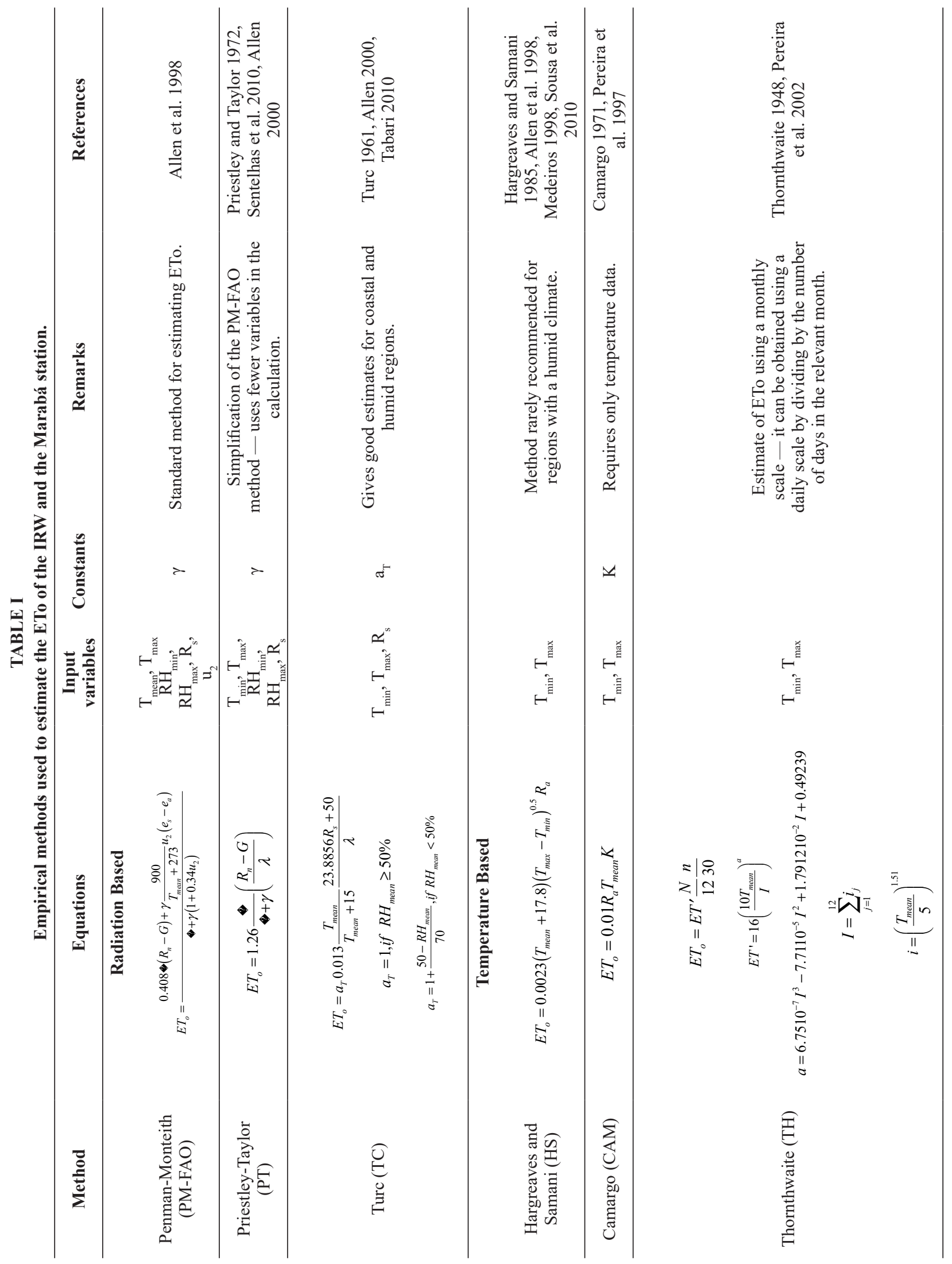


transpiration is the main source of the regional ET, which would be linked to the primary forest.

All aspects of tropical hydrology - from fluxes of energy and water within the atmosphere, to those within vegetation, land surface and subsurface systems, to stream outputs of water, sediment and solutes - are distinguished from other regions of the globe by substantially greater spatial and temporal variability, higher magnitudes, pronounced spatial gradients, and consequently the potential for rapid and significant change in response to anthropogenic alterations and associated water fluxes (Wohl et al. 2012).

In accordance with Zhao et al. (2013), in humid regions, evapotranspiration is responsible for approximately $50 \%$ of the annual rainfall, whereas in arid regions, the proportion reaches $90 \%$. Studies on the atmospheric-hydrological balance of the Amazon (Zeng 1999, Costa and Foley 1999, Roads et al. 2002, Marengo 2005) concluded that the ET represents approximately 59 to $82 \%$ of the rainfall. Besides, they consider that ETo estimation methods based on the energy balance, such as Turc (areas of pasture) and Priestley-Taylor (moist surfaces), are the most suitable for humid regions.

Finally, using meteorological data, Tabari (2010) tested the methods of Makkink, Turc, Priestley-Taylor, and Hargreaves in four climate types in northern Iran and found that the Turc (TC) model is the most suitable for estimating the ETo in climates that are cold, humid and arid. Using monthly meteorological data (1980-2010) from 30 stations located in the northeast of India, where the climate is predominantly humid subtropical, Pandey et al. (2016) showed that of the 18 methods evaluated, temperature and solar radiation based methods - for example, Turc (TC) — were among the three with the best performance. 


\section{RESULTS AND DISCUSSION}

\section{MONTHLY ETO VALUES ESTIMATED FOR THE IRW}

The monthly mean values $\left(\mathrm{mm}^{\mathrm{d}} \mathrm{d}^{-1}\right)$ estimated for all the methods, except the Karrufa (KF), establish a striking ETo signature throughout the year for the basin (Figure 2). Between January and April, the values are relatively constant - the minimum values oscillate between 3.31 and $3.43 \mathrm{~mm} \mathrm{~d}^{-1}$, whereas the maximum values range from 4.81 to $4.94 \mathrm{~mm} \mathrm{~d}^{-1}$. In May and June, there is a slight decline; however, beginning in July, the minimum (3.56 to $3.82 \mathrm{~mm} . \mathrm{d}^{-1}$ ) and maximum (5.33 to 5.57 $\left.\mathrm{mm} . \mathrm{d}^{-1}\right)$ values increase, with the peak occurring in September (3.82 to $5.57 \mathrm{~mm} \cdot \mathrm{d}^{-1}$ ), and then decline until December, when the lowest ETo value was recorded (3.24 mm.d ${ }^{-1}$, Figure 2). The ETo values indicated by the KF method are higher and entirely discordant when compared with those derived from the other employed methods (Figure 2). For this reason they will not be further considered.

The use of the PM-FAO56 reference equation resulted in relatively constant values between January and March (3.37 mm. $\left.\mathrm{d}^{-1}\right)$ and an increase starting in April (3.44 mm. $\left.\mathrm{d}^{-1}\right)$, with a peak in August (4.44 mm. $\left.\mathrm{d}^{-1}\right)$. There was a subsequent decline between September $\left(4.27 \mathrm{~mm} . \mathrm{d}^{-1}\right)$ and December $\left(3.38 \mathrm{~mm} \cdot \mathrm{d}^{-1}\right)$. The equations of Thornthwaite $(\mathrm{TH})$, Camargo (CAM), and Hargreaves and Samani (HS) showed very similar behavior. Between January and April, the ETo values were relatively constant, with the lowest values in June. From July to September, the values increased monthly and then declined between October and December. The equation of Camargo (CAM) estimated the highest ETo values for both the rainy (4.51 to 4.96 $\left.\mathrm{mm} \cdot \mathrm{d}^{-1}\right)$ and dry (4.38 to $5.43 \mathrm{~mm} \cdot \mathrm{d}^{-1}$ ) seasons with exception for the month of September when the TH method presented the highest estimate $\left(5.57 \mathrm{~mm} . \mathrm{d}^{-}\right.$ $\left.{ }^{1}\right)$. In turn, the equation of Turc (TC) had the lowest ETo values for both the rainy (3.24 to $3.61 \mathrm{~mm} . \mathrm{d}^{-1}$ ) and dry (3.85 to $\left.4.09 \mathrm{~mm} . \mathrm{d}^{-1}\right)$ seasons.
The behavior suggested by the mentioned authors before (Zhao et al. 2013, Zeng 1999, Costa and Foley 1999, Roads et al. 2002, Marengo 2005) is observed for the IRW in Figure 2, when comparing the curve of the mean monthly values of cumulative rainfall and the mean ETo values throughout the year. During the rainy season, between January and May (Moraes et al. 2005, Silva Júnior et al. in press), the ETo remains almost constant. Then, from the beginning of the dry season (June), when the lowest accumulated rainfall values are recorded, the ETo increases gradually and reaches a peak in September, specially the TH, HS and CAM methods. With the return of the rains, specifically starting in October, the ETo values begin to decline and then remain constant up to January. However, more studies are necessary to better define these relationships, for example, to determine the role of the forest in the production and/or storage of water and to determine the response of annual evapotranspiration to changes in the vegetation cover due to different types of land use and occupation in the IRW.

The temporal and spatial variability of ETo for IRW show has strong seasonality, increasing during the dry season and decreasing during the rainy season in accordance with Hasler and Avissar (2007). This study corroborates the observations of Zhao et al. (2013) - Figures 2 and 3 show that the TC and PT methods exhibit similar behavior throughout the year for both the Marabá station and the IRW. However, the PT method always overestimates the ETo values throughout the year compared to the PM and TC methods.

Figure 3 shows the estimated ETo values for the Marabá station. Among the eight equations compared, Kharrufa (KF) once again overestimates the ETo values for the whole year, extrapolating the mean behavior of the values generated by the other methods. For the other seven equations, the distribution of the mean monthly values establishes a signature whose maximum monthly ETo values are 


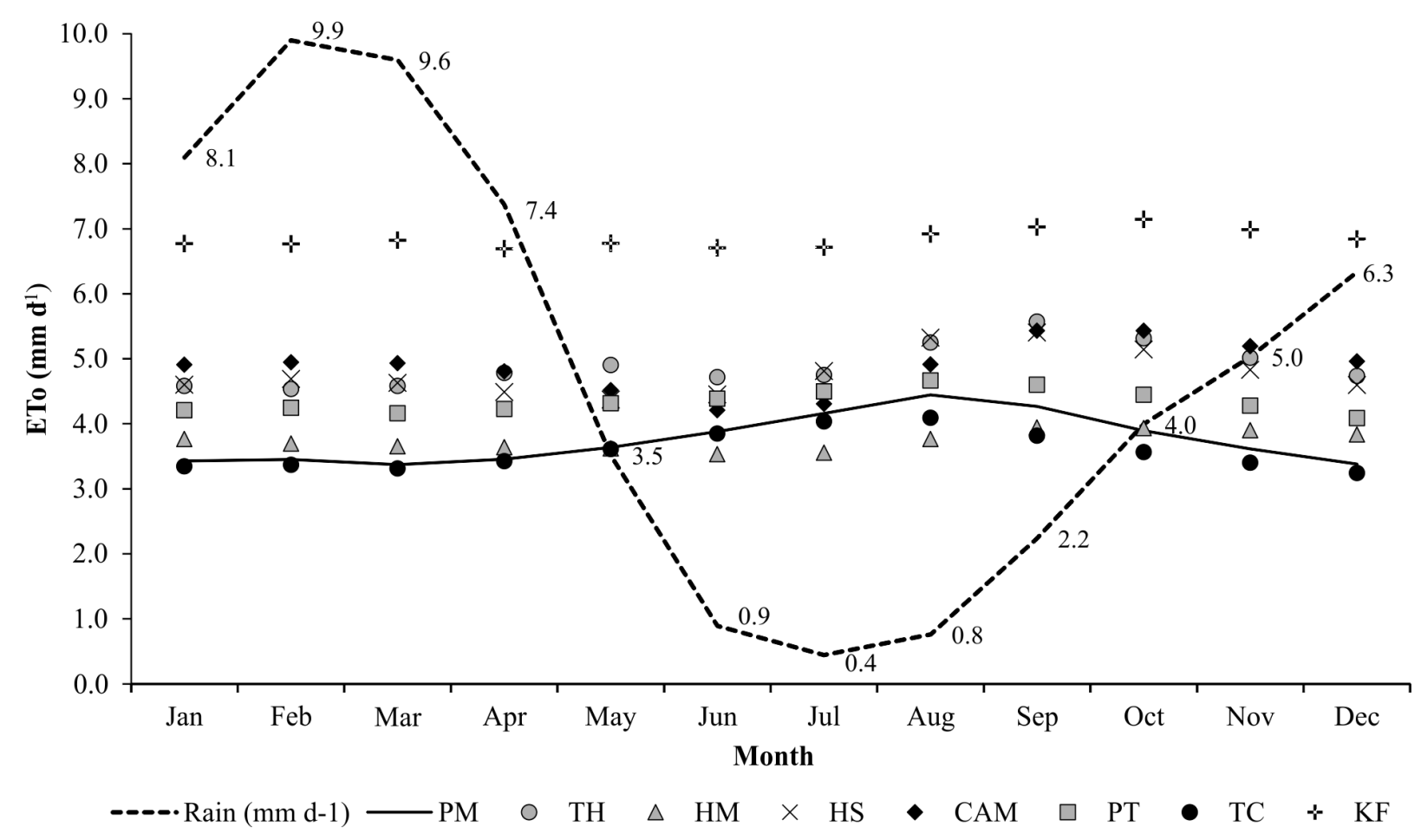

Figure 2 - Comparison between the behavior of rainfall and ETo, expressed in $\mathrm{mm} . \mathrm{d}^{-1}$, obtained via eight empirical methods for the IRW throughout the year for 1980-2013. Rain = Rainfall; PM = Penman-Monteith; TH = Tornthwaite; HM = Hamon; HS = Hargreaves-Samani; CAM = Camargo; PT $=$ Priestley-Taylor; $\mathrm{TC}=$ Turc; KF $=$ Kharrufa.

represented by the distribution of Camargo (CAM), which shows a higher mean value $\left(5.19 \mathrm{~mm} . \mathrm{d}^{-1}\right)$ in the rainy season (November to May) than in the dry season (5.13 mm.d $\mathrm{d}^{-1}$, June to October). This behavior may be interpreted as irregular, as the ETo tends to be higher in environments in which solar radiation levels and mean temperatures are also high, in a directly proportional relationship. The monthly minima follow the distribution curve of the values estimated by Turc (TC), which accompanies the distribution of Penmam-Monteith (PM-FAO 56) - between January and June, the values are very close, and they increase until August. From July until December, Turc (TC) underestimates the values of the PM reference equation (FAO56), as evidenced by a separation of the curves.

The highest values of evapotranspiration observed in our studies occur during the dry season.
These results, obtained through the PM-FAO56 and TC equations, based mainly on solar radiation and temperature, show great similarity with the results of other studies in the region (Souza Filho et al. 2005, Sousa et al. 2007). As well as the studies carried out by Pandey et al. (2016) in northeastern India, where the climate is predominantly humid subtropical, whose methods based on solar radiation - for example, Turc (TC) - were among the top three. The range obtained for IRW is from 3.3 to $3.8 \mathrm{~mm} \cdot \mathrm{d}^{-1}$ in the rainy season and from 3.8 to $4.6 \mathrm{~mm} . \mathrm{d}^{-1}$ in the dry season, according to Negrón Juárez et al. (2007).

The temporal distribution of ETo compared to $\mathrm{R}_{\mathrm{s}}$ (Figure 4) showed similar behavior. It can be seen that $\mathrm{R}_{\mathrm{s}}$ can be considered as the predominant meteorological element on the ETo result. These results are in line with those found by Chang (1968) 


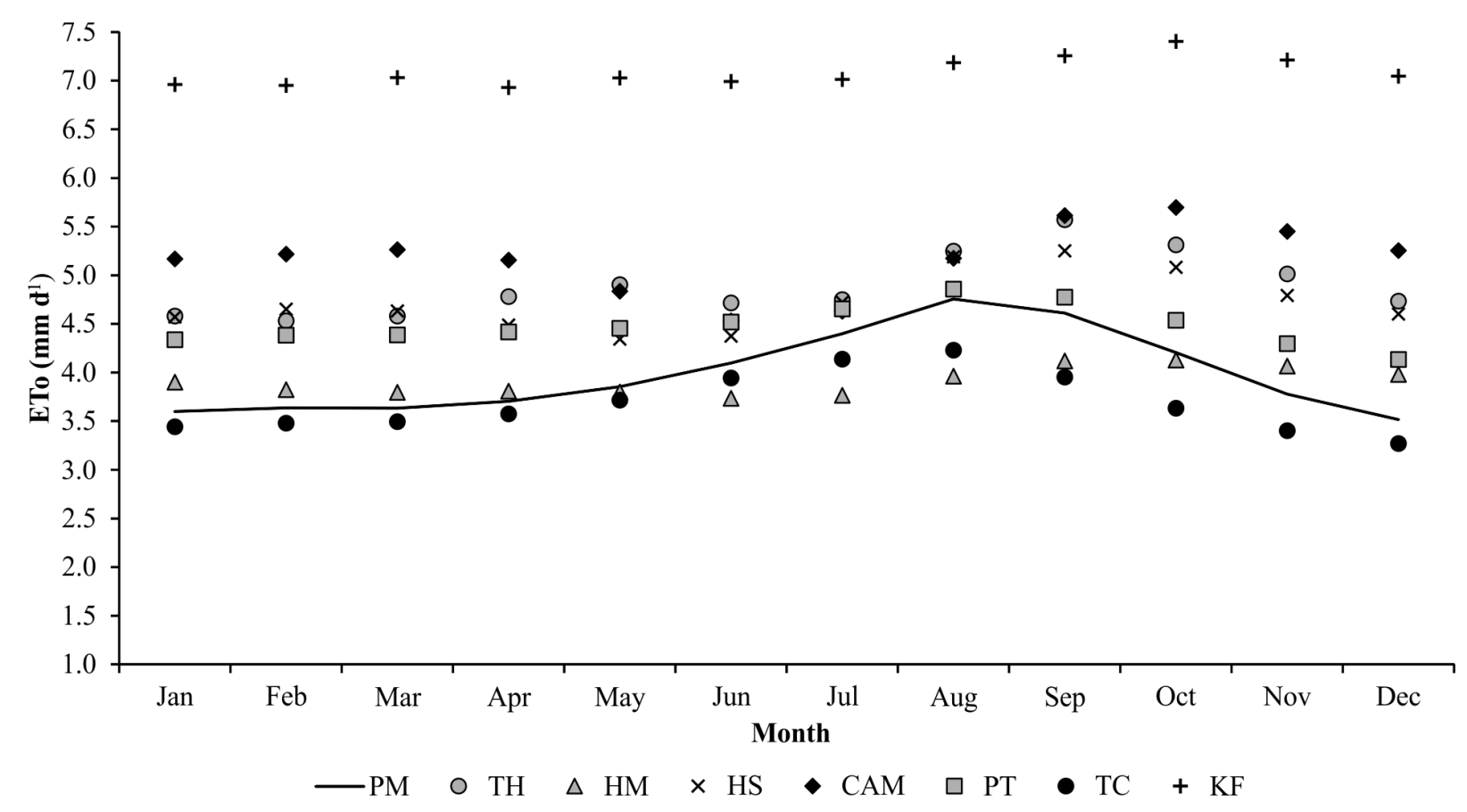

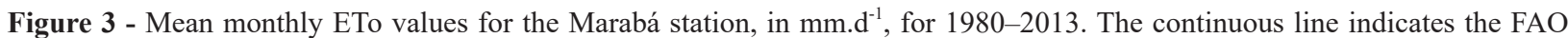
Penman-Monteith method (PM-FAO56); $\mathrm{TH}=$ Tornthwaite; HM = Hamon; HS = Hargreaves-Samani; CAM = Camargo; PT = Priestley-Taylor; TC $=$ Turc; $\mathrm{KF}=$ Kharrufa.

and Nandagiri and Kovoor (2005), who found that $\mathrm{R}_{\mathrm{s}}$ is the quantitative element in the ETo process. In Figure 4, it is also seen that, in general, the periods (between July and August) that present the highest values of $\mathrm{R}_{\mathrm{s}}\left(\approx 18-19 \mathrm{MJ} \cdot \mathrm{m}^{2} \cdot \mathrm{d}^{-1}\right)$ correspond to the same periods where the highest values of Reference evapotranspiration. In other words, the behavior of the solar radiation $\left(\mathrm{R}_{\mathrm{s}}\right)$ presented seasonal characteristics of the global radiation transmission in the local atmosphere, whose maximum values occur from the beginning (May) of the dry season and the minimum values $\left(<16 \mathrm{MJ} . \mathrm{m}^{2} . \mathrm{d}^{-1}\right)$ are recorded during the rainy season (November to April).

\section{STATISTICAL ANALYSIS}

It is important to note that the performance classification for model selection was based on the statistical results of the estimates of all the tests. Thus, the best fitting model was chosen considering that, the estimated model satisfies all the estimates. The options cited in the literature for linear and linearizable models were tested (Maddala and Lahiri 2009, Gujarati and Porter 2011).

The dependent variable is the estimated reference evapotranspiration $\left(\mathrm{ETo}_{\mathrm{IRW}}\right)$, and the explanatory variables are mean temperature $\left(\mathrm{T}_{\text {mean }}\right.$ $=\beta 1)$, solar radiation $\left(\mathrm{R}_{\mathrm{s}}=\beta 2\right)$, relative air humidity $(\mathrm{RH}=\beta 3)$, and wind velocity $\left(\mathrm{V}_{\mathrm{w}}=\beta 4\right)$. The results suggest that the Turc (TC) model has the best fit. Table II shows that the approximation using the $\mathrm{TC}$ equation has the smallest systematic error ( $\mathrm{Se}$ $=0.00051)$, an excellent value for the adjusted coefficient of determination $\left(\mathrm{R}^{2}=1.00\right)$, a low value in the Kolmogorov-Smirnov test of normality (K-S $=0.01)$, and the best result in the Durbin-Watson autocorrelation test $(\mathrm{D}-\mathrm{W}=1.747)$. The $\mathrm{PM}$ and PT methods had the second and third best results, respectively. For the PM method, $\mathrm{R}^{2}=0.975$, whereas for PT, $\mathrm{R}^{2}=0.94$. The systematic error in 


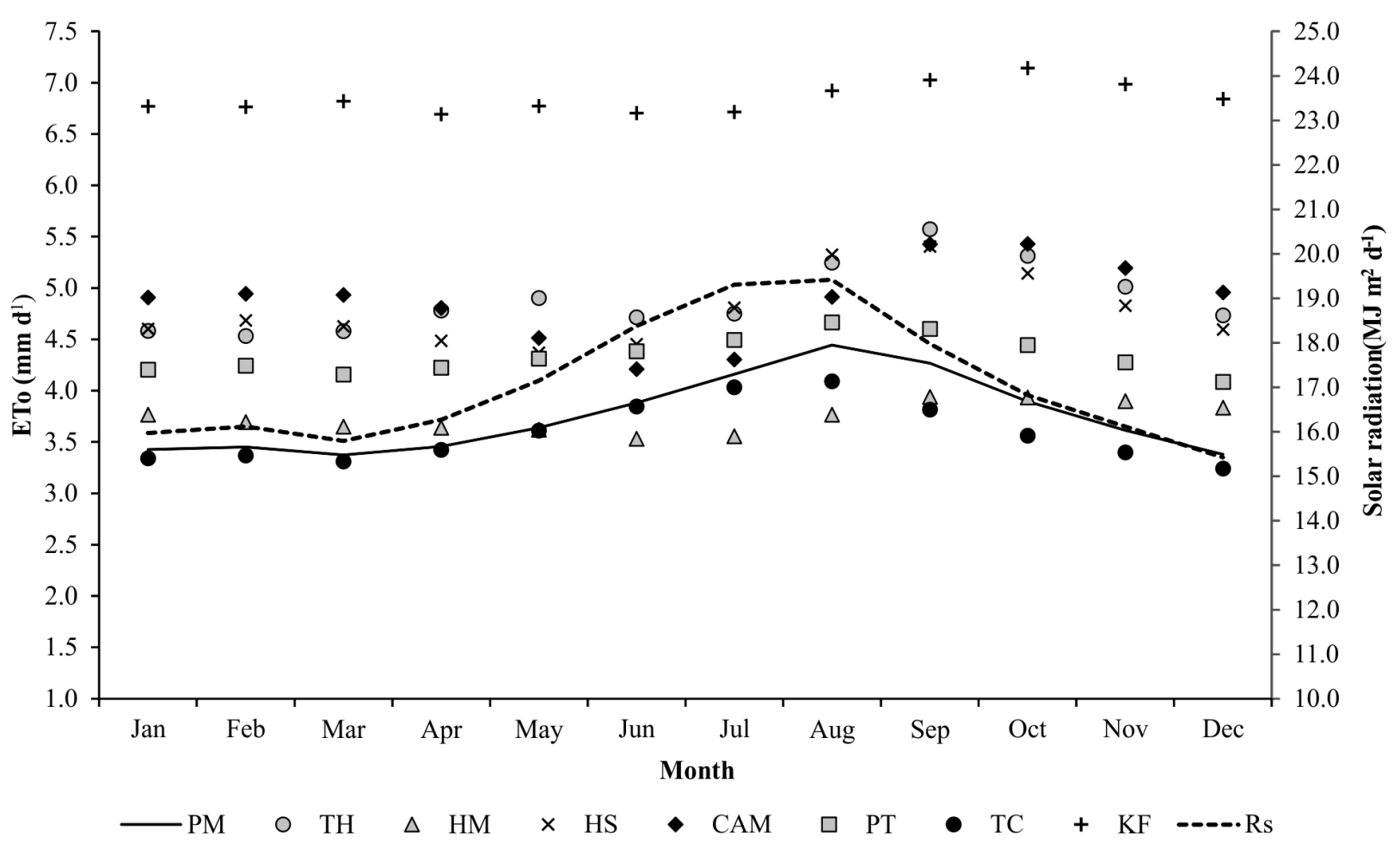

Figura 4 - Behavior of ETo, in mm.d $\mathrm{d}^{-1}$, and solar radiation $\left(\mathrm{R}_{\mathrm{s}}\right)$, in $\mathrm{MJ} \mathrm{m}^{2} \cdot \mathrm{d}^{-1}$, throughout the year at IRW for 1980-2013.

$\mathrm{PT}(\mathrm{Se}=0.02)$ is smaller than that in $\mathrm{PM}(\mathrm{Se}=0.19)$; however, in the normality test, the PM value $(\mathrm{K}-\mathrm{S}=$ $0.161)$ is smaller than that for PT $(\mathrm{K}-\mathrm{S}=0.205)$. The result of the D-W autocorrelation test — despite the PM and PT equations using more parameters than TC - showed significant values at the 5\% level, indicating that there is no autocorrelation of the residuals and that one residual is not correlated with another over the years analyzed (Figures 5a and 5b), as per Gujarati and Porter (2011).

In this context, using a level of significance of $1 \%$, all the statistics of the Turc model adjusted for $\mathrm{ETo}_{\text {IRW }}$ strongly agree with the reference evapotranspiration estimates, whose equation is

$$
\boldsymbol{E T T o}_{\text {IRW }}=(0.0743) \cdot\left(\boldsymbol{T}_{\text {mean }}\right)^{0.358} \cdot\left(\boldsymbol{R}_{s}\right)^{0.951} \cdot(\boldsymbol{R H})^{-0.001}
$$

For the Marabá station, the results from the statistical tests suggest that the Penman-Monteith model (PM-FAO 56) has the best fit for the data recorded (Table III). The PM equation has the lowest systematic error $(\mathrm{Se}=0.0041)$; an excellent value for the adjusted coefficient of determination $\left(\mathrm{R}^{2}=0.997\right)$; a suitable value in the KolmogorovSmirnov normality test $(\mathrm{K}-\mathrm{S}=0.663)$; and the best result in the Durbin-Watson autocorrelation test ( $\mathrm{D}-\mathrm{W}=1.506)$, as per the range established for the four-parameter condition, in accordance with Gujarati and Porter (2011).

For the other models (Table III), the adjusted coefficients of determination $\left(\mathrm{R}^{2}=1.00,0.999\right.$, and 0.999 for KF, PT, and HM, respectively) for the corresponding models are excellent — suggesting good correlation - and the systematic errors are very low $(\mathrm{Se}=0.00035,0.00119$, and 0.00082 for $\mathrm{KF}$, PT, and HM, respectively). However, the D-W autocorrelation test yields values that exceed the range established for the number of parameters used in each case.

Thus, at the $1 \%$ significance level, all the statistics of the PM model adjusted for $\mathrm{ETo}_{\text {Marabá }}$ 
TABLE II

Summary of the estimates and statistical tests of the ETo models for the IRW $(N=408)$.

\begin{tabular}{|c|c|c|c|c|c|c|c|c|c|c|c|c|}
\hline \multirow{2}{*}{$\begin{array}{c}\text { Method } \\
\text { Tests } \\
\end{array}$} & \multicolumn{3}{|c|}{ Penman-Monteith (PM) } & \multicolumn{3}{|c|}{ Priestley-Taylor (PT) } & \multicolumn{3}{|c|}{ Hargreaves and Samani (HS) } & \multicolumn{3}{|c|}{ Camargo (CAM) } \\
\hline & Coeff. & t-test & Sig & Coeff. & t-test & Sig & Coeff. & t-test & Sig & Coeff. & t-test & Sig \\
\hline$\beta_{0}$ & -2.266 & -14.944 & 0.000 & -4.996 & -31.119 & 0.000 & -5.187 & -18.943 & 0.000 & -4.297 & -9.181 & 0.000 \\
\hline$\beta_{1}$ & 0.924 & 26.061 & 0.000 & 0.878 & 23.402 & 0.000 & 2.031 & 24.558 & 0.000 & 1.686 & 15.406 & 0.000 \\
\hline $\boldsymbol{\beta}_{2}$ & 0.661 & 49.993 & 0.000 & 0.782 & 55.871 & 0.000 & - & - & - & -0.286 & -7.013 & 0.000 \\
\hline $\boldsymbol{\beta}_{3}$ & -0.311 & -22.556 & 0.000 & 0.308 & 21.058 & 0.000 & - & - & - & 0.249 & 5.853 & 0.000 \\
\hline \multirow[t]{2}{*}{$\boldsymbol{\beta}_{4}$} & 0.113 & 12.984 & 0.000 & 0.047 & 5.066 & 0.000 & 0.219 & 10.257 & 0.000 & 0.099 & 3.685 & 0.000 \\
\hline & 0.975 & - & - & 0.94 & - & - & 0.627 & - & - & 0.429 & - & - \\
\hline Se & 0.1939 & - & - & 0.02053 & - & - & 0.05351 & - & - & 0.05987 & - & - \\
\hline $\mathbf{F}$ & 3959.795 & - & - & 1599.835 & - & - & 342.362 & - & - & 77.388 & - & - \\
\hline K-S & - & - & 0.161 & - & - & 0.205 & - & - & 0.127 & - & - & 0.000 \\
\hline D-W & 0.643 & - & - & 0.519 & - & - & 0.744 & - & - & 0.56 & - & - \\
\hline Method & \multicolumn{3}{|c|}{ Thornthwaite (TH) } & \multicolumn{3}{|c|}{ Hamon (HM) } & \multicolumn{3}{|c|}{ Kharrufa (KF) } & \multicolumn{3}{|c|}{ Turc (TC)* } \\
\hline Tests & Coeff. & t-test & Sig & Coeff. & t-test & Sig & Coeff. & t-test & Sig & Coeff. & t-test & Sig \\
\hline $\boldsymbol{\beta}_{0}$ & -10.513 & -121.666 & 0.000 & -4.505 & -20.83 & 0.000 & -2.471 & -22.923 & 0.000 & -2.599 & -706.541 & 0.000 \\
\hline$\beta_{1}$ & 3.705 & 128.005 & 0.000 & 1.787 & 33.214 & 0.000 & 1.3 & 48.457 & 0.000 & 0.358 & 391.517 & 0.000 \\
\hline$\beta_{2}$ & -0.05 & -5.92 & 0.000 & -0.14 & -7.077 & 0.000 & -0.048 & -4.902 & 0.000 & 0.951 & 2817.773 & 0.000 \\
\hline$\beta_{3}$ & - & - & - & 0.073 & 3.827 & 0.000 & 0.055 & 5.794 & 0.000 & -0.001 & -3.404 & 0.001 \\
\hline \multirow[t]{2}{*}{$\boldsymbol{\beta}_{4}$} & 0.021 & 3.233 & 0.001 & - & - & - & - & - & - & - & - & - \\
\hline & 0.981 & - & - & 0.734 & - & - & 0.863 & - & - & 1.000 & - & - \\
\hline Se & 0.01625 & - & - & 0.02991 & - & - & 0.01491 & - & - & 0.00051 & - & - \\
\hline F & 6921.071 & - & - & 375.731 & - & - & 854.441 & - & - & 6444866 & - & - \\
\hline K-S & - & - & 0.103 & - & - & 0.006 & - & - & 0.000 & - & - & 0.01 \\
\hline D-W & 0.792 & - & - & 0.439 & - & - & 0.994 & - & - & 1.747 & - & - \\
\hline
\end{tabular}

Source: Prepared by the authors for the IRW, based on data from Xavier et al. (2015). The models tested were the linear and double-log models, in which $\boldsymbol{\beta}_{0}=$ model constant; $\boldsymbol{\beta}_{1}=$ mean air temperature; $\boldsymbol{\beta}_{2}=$ solar radiation; $\boldsymbol{\beta}_{3}=$ relative air humidity; $\boldsymbol{\beta}_{4}=$ wind velocity; = adjusted coefficient of determination; $\mathbf{S e}=$ standard error of estimate; $\mathbf{F}=$ Fisher's F-test; K-S = Kolmogorov-Smirnov test of normality; $\mathbf{D}-\mathbf{W}=$ Durbin-Watson autocorrelation test. *Method with best fit.

strongly agree with the estimated reference evapotranspiration, whose equation is

$$
\boldsymbol{E} \boldsymbol{E} \boldsymbol{o}_{\text {Marabia }}=(0.3922) \cdot\left(\boldsymbol{T}_{\text {mean }}\right)^{0.732} \cdot\left(\boldsymbol{R}_{\boldsymbol{s}}\right)^{0.698} \cdot(\boldsymbol{R} \boldsymbol{H})^{-0.494}\left(\boldsymbol{V}_{w}\right)^{0.092}
$$

The estimates of the adjusted coefficient of determination and standard error of the estimate are extremely significant (0.997 and 0.0041, respectively). The test statistics for the DurbinWatson autocorrelation test $(\mathrm{D}-\mathrm{W}=1.506)$ indicate that the residuals show no relationship between the dry and rainy seasons at the $1 \%$ level of significance; that is, the residual of a dry season is not correlated with the corresponding residual of a rainy season. In other words, the seasons are well defined, and there is no influence from the climatological results of one season on the other. Fisher's F-test (equal to 2.555) extrapolates the estimates of tests reported in the current literature (Maddala and Lahiri 2009, Gujarati and Porter 2011) and indicates that together, the explanatory variables suggest the existence of a Cobb-Douglas relationship (regression with double $\log$ ) in the dependent and independent variables for the data of the entire basin.

The Student's t-test statistics are significant at the $1 \%$ level and indicate that the mean temperature, 

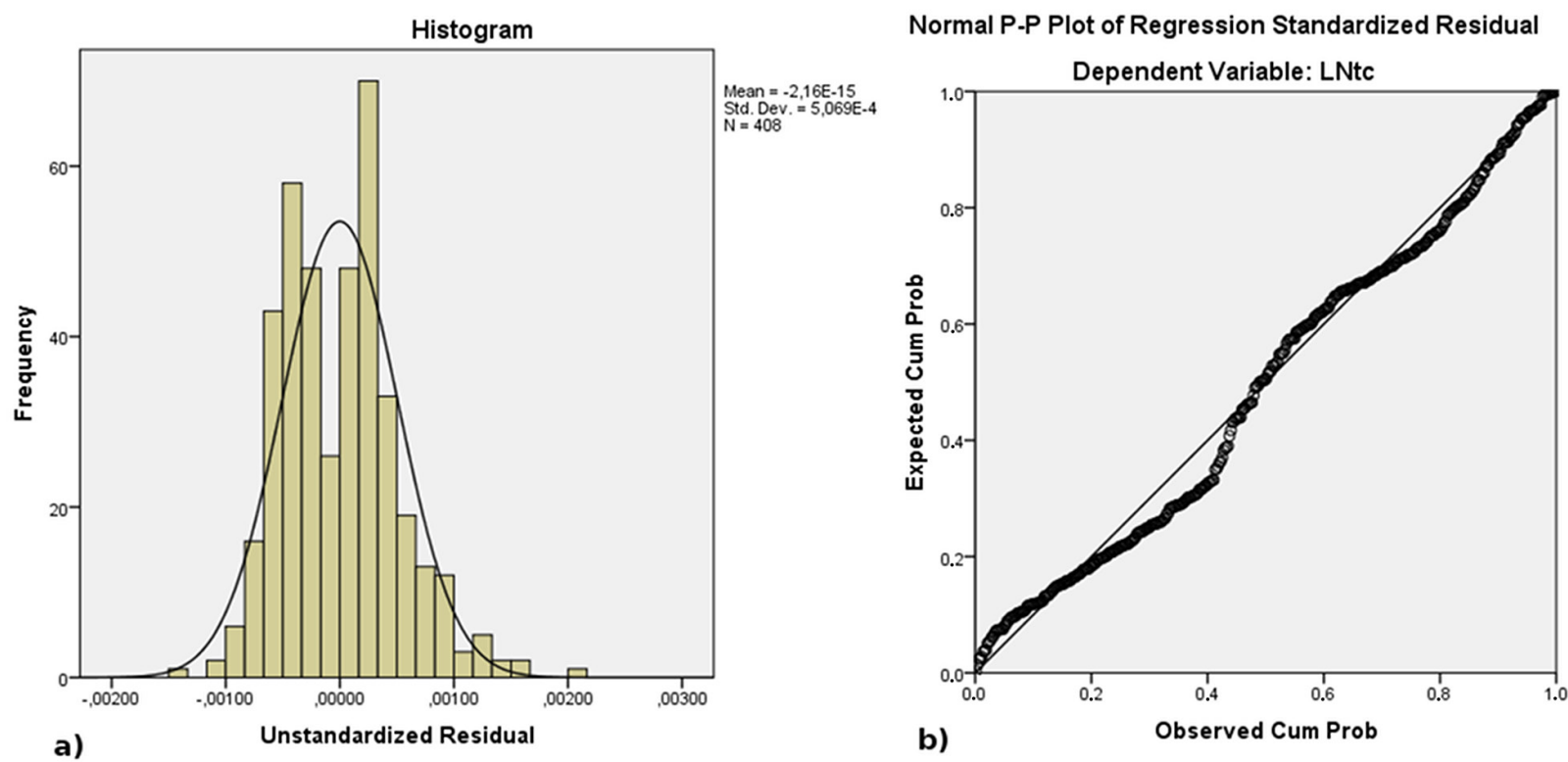

Figure 5 - a) Histogram with normal distribution of the residuals of the fitted ETo model for the IRW, and b) observed and expected probabilities of the ETo model for the IRW.

TABLE III

Summary of the estimates and statistical tests of the ETo models for the Marabá station $(\mathrm{N}=34)$.

\begin{tabular}{|c|c|c|c|c|c|c|c|c|c|c|c|c|}
\hline \multirow{2}{*}{$\frac{\text { Method }}{\text { Tests }}$} & \multicolumn{3}{|c|}{ Penman-Monteith (PM)* } & \multicolumn{3}{|c|}{ Priestley-Taylor (PT) } & \multicolumn{3}{|c|}{ Hargreaves and Samani (HS) } & \multicolumn{3}{|c|}{ Camargo (CAM) } \\
\hline & Coeff. & t-test & Sig & Coeff. & t-test & Sig & Coeff. & t-test & Sig & Coeff. & t-test & Sig \\
\hline $\boldsymbol{\beta}_{0}$ & -0.936 & -4.311 & 0.000 & -4.39 & -69.034 & 0.00 & -2.993 & -3.073 & 0.004 & -5.315 & -11.182 & 0.000 \\
\hline $\boldsymbol{\beta}_{1}$ & 0.732 & 15.827 & 0.000 & 0.701 & 51.783 & 0.00 & 1.384 & 4.657 & 0.000 & 1.999 & 17.714 & 0.000 \\
\hline $\boldsymbol{\beta}_{2}$ & 0.698 & 31.341 & 0.000 & 0.25 & 44.1 & 0.00 & - & - & - & - & - & - \\
\hline $\boldsymbol{\beta}_{3}$ & -0.494 & -25.552 & 0.000 & 0.865 & 132.625 & 0.00 & - & - & - & 0.065 & 1.725 & 0.095 \\
\hline \multirow[t]{2}{*}{$\boldsymbol{\beta}_{4}$} & 0.092 & 7.17 & 0.000 & -0.011 & -2.87 & 0.008 & -0.194 & -2.095 & 0.044 & 0.052 & 1.689 & 0.102 \\
\hline & 0.997 & - & - & 0.999 & - & - & 0.376 & - & - & 0.945 & - & - \\
\hline $\mathrm{Se}$ & 0.0041 & - & - & 0.00119 & - & - & 0.03016 & - & - & 0.1 & - & - \\
\hline $\mathbf{F}$ & 2554.822 & - & - & 9539.526 & - & - & 10.941 & - & - & 189.207 & - & - \\
\hline $\mathbf{K}-\mathbf{S}$ & - & - & 0.663 & - & - & 0.958 & - & - & 0.196 & - & - & 0.504 \\
\hline D-W & 1.506 & - & - & 2.213 & - & - & 1.881 & - & - & 1.863 & - & - \\
\hline Method & \multicolumn{3}{|c|}{ Thornthwaite (TH) } & \multicolumn{3}{|c|}{ Hamon (HM) } & \multicolumn{3}{|c|}{ Kharrufa (KF) } & \multicolumn{3}{|c|}{ Turc (TC) } \\
\hline Tests & Coeff. & t-test & Sig & Coeff. & t-test & Sig & Coeff. & t-test & Sig & Coeff. & t-test & Sig \\
\hline $\boldsymbol{\beta}_{\mathrm{o}}$ & -4.837 & -2.324 & 0.027 & -4.398 & -115.858 & 0.00 & -2.355 & -147.039 & 0.00 & -2.248 & -13.83 & 0.00 \\
\hline $\boldsymbol{\beta}_{1}$ & 1.929 & 3.086 & 0.004 & 1.737 & 203.237 & 0.00 & 1.299 & 360.052 & 0.00 & 0.273 & 4.814 & 0.00 \\
\hline $\boldsymbol{\beta}_{2}$ & - & - & - & - & - & - & - & - & - & 0.925 & 37.846 & 0.00 \\
\hline $\boldsymbol{\beta}_{3}$ & - & - & - & -0.006 & -1.799 & 0.082 & -0.003 & -1.995 & 0.055 & - & - & - \\
\hline \multirow[t]{2}{*}{$\boldsymbol{\beta}_{4}$} & - & - & - & - & - & - & - & - & - & - & - & - \\
\hline & 0.205 & - & - & 0.999 & - & - & 1.000 & - & - & 0.986 & - & - \\
\hline $\mathrm{Se}$ & 0.07484 & - & - & 0.00082 & - & - & 0.00035 & - & - & 0.00574 & - & - \\
\hline $\mathbf{F}$ & 9.523 & - & - & 32411.27 & - & - & 101320.550 & - & - & 1150.441 & - & - \\
\hline
\end{tabular}


TABLE III (continuation)

\begin{tabular}{|c|c|c|c|c|c|c|c|c|c|c|c|c|}
\hline Method & \multicolumn{3}{|c|}{ Thornthwaite (TH) } & \multicolumn{3}{|c|}{ Hamon (HM) } & \multicolumn{3}{|c|}{ Kharrufa (KF) } & \multicolumn{3}{|c|}{ Turc (TC) } \\
\hline Tests & Coeff. & $\mathrm{t}$-test & Sig & Coeff. & t-test & Sig & Coeff. & t-test & Sig & Coeff. & t-test & Sig \\
\hline K-S & - & - & 0.008 & - & - & 0.748 & - & - & 0.979 & - & - & 0.234 \\
\hline D-W & 0.251 & - & - & 2.276 & - & - & 2.290 & - & - & 0.374 & - & - \\
\hline
\end{tabular}

Source: Prepared by the authors based on annual data from the Marabá station (1980-2013). The models tested were the linear and the $\log$ models, in which $\boldsymbol{\beta}_{0}=$ model constant; $\boldsymbol{\beta}_{1}=$ mean air temperature; $\boldsymbol{\beta}_{2}=$ solar radiation; $\boldsymbol{\beta}_{3}=$ relative air humidity; $\boldsymbol{\beta}_{4}=$ wind velocity; = adjusted coefficient of determination; $\mathbf{S e}=$ standard error of estimate; $\mathbf{F}=$ Fisher's F-test; K-S $=$ KolmogorovSmirnov test of normality; D-W = Durbin-Watson autocorrelation test. *Method with best fit.

solar radiation, relative air humidity, and wind velocity variables explain the variations recorded in the reference evapotranspiration (ETo). This is in agreement with the evidence that a $1 \%$ increase in the mean temperature results in a $0.358 \%$ increase in the ETo. The estimated $\beta$ coefficients represent the climate elasticities for the Marabá station, as a positive variation of $1 \%$ in the solar radiation causes an almost proportional increase $(\beta=0.698)$ in the estimated ETo for said station, which can also be corroborated by the relevance in terms of estimating the standardized $\beta$ values (standardized $\beta=0.469$ ). A positive variation in the relative air humidity has a negative effect on the ETo estimated for the Marabá station. The Kolmogorov-Smirnov normality test indicates that at the $1 \%$ significance level, the errors are distributed normally, leading to the well-defined, or normal, behavior of the residuals in the area of the standard normal distribution (Figures 6a and 6b).

Thus, more detailed studies are needed on the behavior and temporal variability of meteorological parameters $\left(R_{s}, T_{\text {mean }}, R H\right.$, and $\left.V_{w}\right)$ due to changes in land use and vegetation cover, as well as on the level of influence of El Niño and La Niña events or other climate drivers on the eastern Amazon and, in particular, the IRW.

\section{CONCLUSIONS}

The ETo for the IRW and the Marabá station can be reliably estimated from methods based on solar radiation $\left(R_{s}\right)$ and mean air temperature $\left(T_{\text {mean }}\right)$.
Among the eight methods evaluated, the Turc (TC), Penman-Monteith (PM-FAO 56) and PriestleyTaylor (PT) methods satisfy these requirements, but TC and PM methods showed the best fits.

The temporal and spatial variability of ETo for IRW show has strong seasonality, increasing during the dry season and decreasing during the rainy season. The statistical analyses at $1 \%$ level of significance, indicates that there is no correlation of the residuals between the dry and rainy seasons, and test of the physical parameters such as mean temperature, solar radiation and relative air humidity explains the variations of ETo.

When considering the energy exchanges in the soil-vegetation-atmosphere interface, our results, in particular the superior performance of the radiation-based models, demonstrate that the mean temperature and radiation are the dominant drivers of the evapotranspiration process in the region, whereas relative humidity and wind velocity have a much smaller impact. However, these equations may require calibrations when applied to another region so that they reflect local changes in the climatic variables.

Finally, it is important to emphasize that there were in the past few hydro meteorological stations in the IRW that monitor parameters such as solar radiation, temperature, relative humidity, and wind velocity. Besides the use of direct methods for determining evapotranspiration is non-existent. However, this reality is being transformed, because of the installation of eight automatic stations, 

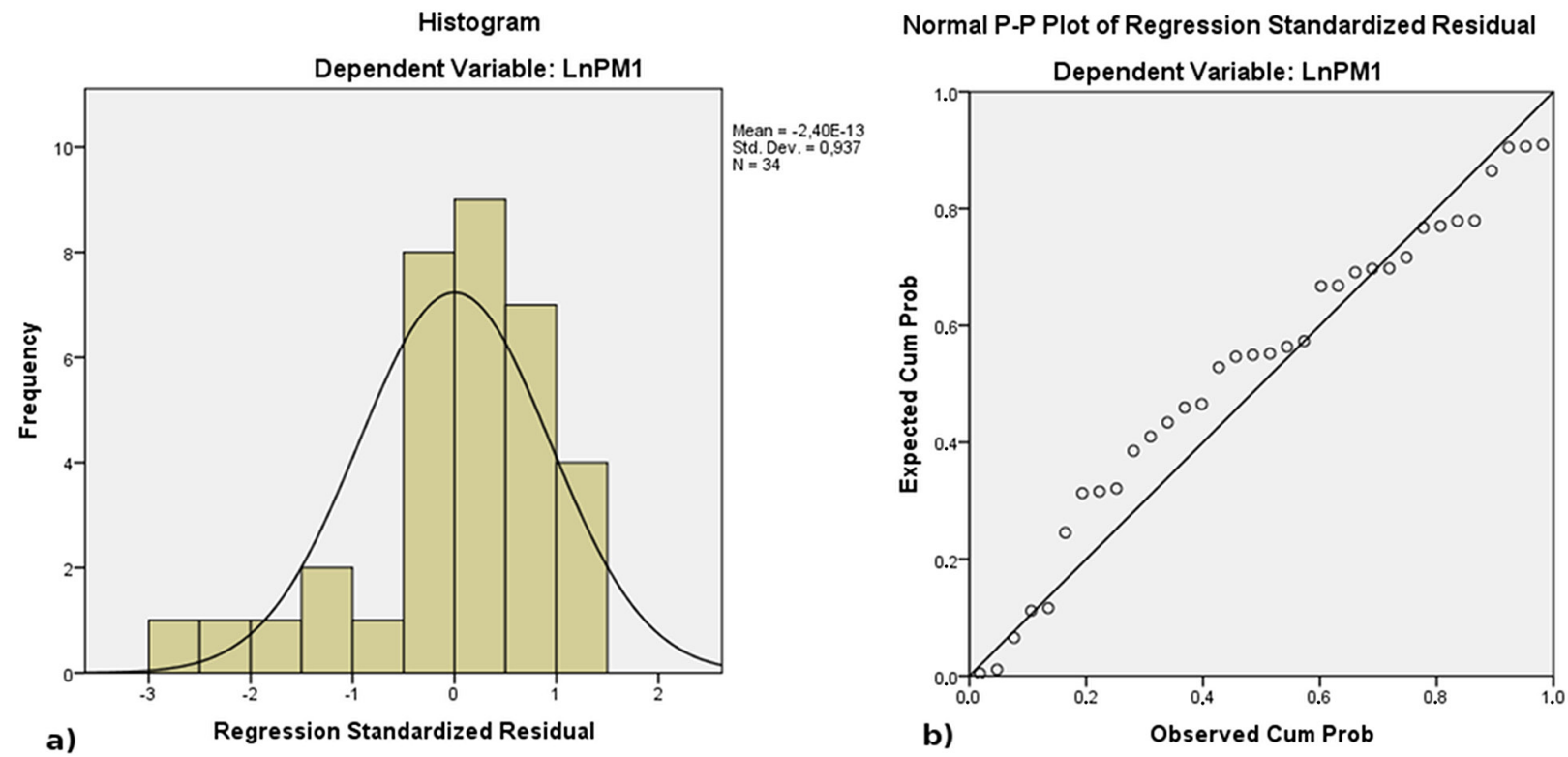

Figure 6 - a) Histogram with normal distribution of the residuals; b) observed and expected probabilities of the fitted ETo model for the IRW.

which will enable the systematic monitoring of hydrometeorological data in the IRW from now.

\section{ACKNOWLEDGMENTS}

We thank the Vale Institute of Technology for the financial and logistical support and the Conselho Nacional de Desenvolvimento Científico e Tecnológico (CNPq) for the Industrial Post-doctoral (PDI) scholarship granted to Alexandra Tavares and the Research Grant to P.W. Souza Filho.

\section{REFERENCES}

ALLEN RG. 2000. Ref-ET: Reference Evapotranspiration Calculation Software for FAO and ASCE Standardized Equations; version 3.1.15. Kimberly: University of Idaho Research and Extension Center ID, USA.

ALLEN RG, PEREIRA LS, RAES D AND SMITH M. 1998. Crop evapotranspiration - Guidelines for computing crop water requirements. Irrig and Drain Pap, 56. U N Food and Agric Organ, Rome.

ALLEN RG ET AL. 2006. A recommendation on standardized surface resistance for hourly calculation of reference ETo by the FAO56 Penman-Monteith method. Agric Water Manage 81: 1-22.

ALLEN RG, WALTER IA, ELLIOT R, HOWELL T, ITENFISU D AND JENSEN M. 2005. The ASCE standardized reference evapotranspiration equation. Final report. Phoenix: National Irrigation Symp. ASCE-EWRI.T ask Committee Retrieved.

ALVARES CA, STAPE JL, SENTELHAS PC, GONÇALVES JLM AND GERD SPAROVEK G. 2014. Köppen's climate classification map for Brazil. Meteorol Z 22: 711-728.

ASCE-EWRI. 2005. The ASCE Standardised Reference Evapotranspiration Equation. Report by the Task Committee on Standard Deviations of Reference Evapotranspiration.

BARROS VR, SOUZA AP DE, FONSECA DC AND SILVA LBD DA. 2009. Avaliação da evapotranspiração de referência na região de Seropédica, Rio de Janeiro, utilizando lisímetro de pesagem e modelos matemáticos. R Bras Eng Agríc Ambiental 4: 198-203.

BASTIAANSSEN WGM, MENENTI M, FEDDES RA AND HOLSLAG AAM. 1998. A remote sensing surface energy balance algorithm for land (SEBAL) - 1. J Hydrol 212: 198-212.

BERTI A, TARDIVO G, CHIAUDANI A, RECH F AND BORIN M. 2014. Assessing reference evapotranspiration by the Hargreaves method in north-eastern Italy. Agric Water Manage 140: 20-25.

BORGES AC DE AND MENDIONDO EM. 2007. Comparação entre equações empíricas para estimativa da evapotranspiração de referência na Bacia do Rio Jacupiranga. R Bras Eng Agríc Ambiental 11: 293-300.

BRASIL. 2003. Conselho Nacional de Recursos Hídricos. Secretaria Recursos Hídricos. Resolução No 32, de 15 de 
outubro de 2003. Disponível em: http://www.cnrh.gov.br. Acessado em 2 de julho de 2016.

CAMARGO AP. 1971. Balanço hídrico no Estado de São Paulo. IAC (Boletim Técnico, 116), 24 p.

CAMARGO AP AND CAMARGO MBP. 2000. Uma revisão analítica da evapotranspiração potencial. Bragantia, Campinas 59: 125-137. Campinas: IAC, 1971, 24 p. Boletim n. 116 .

CAPORUSSO NB AND ROLIM GS. 2015. Reference evapotranspiration models using diferents time scales in the Jaboticabal region of São Paulo, Brazil. Acta Sci Agron 37: $1-9$.

CARVALHO LG, RIOS GFA, MIRANDA WLAND CASTRO NETO P. 2011. Evapotranspiração de Referência: Uma abordagem atual de diferentes métodos de estimativa. Pesq Agropec Trop 41: 456-465.

CHANG J. 1968. Climate and agriculture: An ecological survey. Chicago: Aldine Publishing Company, 304 p.

COSTA MH AND FOLEY JA. 1999. Trends in the hydrologic cycle of the Amazon basin. Geophys Res 104: 1418914198.

DEHGHANI SANIJ H, YAMAMOTO T AND RASIAH V. 2004. Assessment of evapotranspiration estimation models for use in semi-arid environments. Agric Water Manage 64: 91-106.

DJAMAN K, BALDE AB, SOW A, MULLER B, IRMAK S, N'DIAYE MK, MANNEH B AND SAITO K. 2015. Evaluation of sixteen reference evapotranspiration methods under Sahelian conditions in the Senegal River valley. J Hydrol 3: 139-159.

FERREIRA JUNIOR P, SOUSA AM, VITORINO MI, SOUZA EB DE AND SOUZA PJOP DE. 2013. Estimate of evapotranspiration in the eastern Amazon using SEBAL. Rev Cienc Agrar 56: 33-39.

GAVILÁN P, BERENGENA J AND ALLEN RG. 2007. Measuring versus estimating net radiation and soil heat flux: impact on Penman-Monteith reference ET estimates in semiarid regions. Agric Water Manage 89: 275-286.

GAVILÁN P, ESTÉVEZ J DE AND BERENGENA J. 2008. Comparison of standardized reference evapotranspiration equations in southern Spain. J Irrig Drain Eng 134: 1-12.

GHAMARNIA H, MOUSABEYG F, AMIRI S AND AMIRKHANI D. 2015. Evaluation of a few evapotranspiration model susing lysimetric measurements in a semi-arid climate region. Int J Plant Soil Sci 5(2): 100-109.

GUJARATI DN AND PORTER DC. 2011. Econometria Básica, 5, Editora McGraw Hill: Brasil, 924 p.

HAMON WR. 1961. Estimating potential evapotranspiration. J Hydraul Eng ASCE 87: 107- 120.

HARGREAVES GH AND SAMANI ZA. 1985. Reference crop evapotranspiration from temperature. Appl Eng Agric 1: 96-99.
HASLER N AND AVISSAR R. 2007. What Controls Evapotranspiration in the Amazon Basin? J Hydrometeorol 8: 380-395

IRMAK S, IRMAK A, ALLEN RG AND JONES JW. 2003. Solar and net radiation-based equations to estimate reference evapotranspiration in humid climates. J Irrig Drain Eng 129(5): 336-347.

ITENFISU D, ELLIOTT RL, ALLEN RG AND WALTER IA. 2003. Comparison of reference evapotranspiration calculation saspart of the ASCE standardization effort. J Irrig Drain Eng 129(6): 440-448.

JABLOUN M DE AND SAHLI A. 2008. Evaluation of FAO-56 methodology for estimating reference evapotranspiration using limited climatic data application to Tunisia. Agric Water Manage 95: 707-771.

JAIN SK, NAYAK PC AND SUDHEER KP. 2008. Models for estimating evapotranspiration using artificial neural networks, and their physical interpretation. Hydrol Process 22: 2225-2234.

KHARRUFA NS. 1985. Simplified equation for evapotranspiration in arid regions. Beitr Hydrol 5: 39-47.

LIMA J, ANTONINO A, SOUZA E, HAMMECKER C, MONTENEGRO S AND LIRA C. 2013. Calibration of Hargreaves-Samani equation for estimating reference evapotranspiration in the sub-humid region of Brazil. J Water Resource Prot 5: 12A1-A5.

LIU WTH. 2007. Aplicações de sensoriamento remoto. Campo Grande-MS: UNIDERP, 908 p.

LÓPEZ-URREA R, OLALLA FMS, FABEIRO C AND MORATALLA A. 2006. Testing evapotranspiration equations using lysimeter observations in a semiarid climate. Agric Water Manage 85: 15-26.

MACHADO CC, SILVA BB, DE ALBUQUERQUE MB AND GALVINCIO JD. 2014. Estimativa do balanço de energia utilizando imagens TM - Landsat 5 e o algoritmo SEBAL no litoral sul de Pernambuco. Rev Bras Meteorol 29: 5567.

MADDALA GS AND LAHIRI K. 2009. Introduction to Econometrics, 4th ed., England: Chichester, 656 p.

MALHI Y, PEGORARO E, NOBRE AD, PEREIRA MGP, GRACE J, CULF AD AND CLEMENT R. 2002. Energy and water dynamics of a central Amazonian rain forest. J Geophys Res 107: LBA 45-1-LBA 45-17.

MARENGO JA. 2005. The characteristics and variability of the atmospheric water balance in the Amazon basin: Spatial and temporal variability. Clim Dynam 24: 11-22.

MEDEIROS SLP. 1998. Avaliação de métodos de estimativa da evapotranspiração de referência para a região mesoclimática de Santa Maria-RS. RBAgro 6: 105-109.

MOHAN S AND ARUMUGAM N. 1996. Discussion of 'Comparison of methods for estimating REF-ETDiscussion'. J Irrig Drain Eng 122(6): 361-362. 
MORAES BC DE, COSTA JMN DA, COSTA ACL DA AND COSTA MH. 2005. Variação espacial e temporal da precipitação no estado do Pará. Acta Amazon 35: 207-214.

NANDAGIRI L AND KOVOOR GM. 2005. Sensitivity of the Food and Agriculture Organization Penman-Monteith evapotranspiration estimates to alternative procedures for estimation of parameters. J Irrig Drain Eng 131: 238-248.

NANDAGIRI L AND KOVOOR GM. 2006. Performance evaluation of reference evapotranspiration equations across a range of Indian climates. J Irrig Drain Eng 132(3): 238-249.

NEGRÓN JUÁREZ RI, HODNETT MG, FU R, GOULDEN ML AND VON RANDOW C. 2007. Control of Dry Season Evapotranspiration over the Amazonian Forest as Inferred from observations at a Southern Amazon Forest Site. J Climate 20: 2827-2839.

NEPSTAD DC, CARVALHO CR, DAVIDSON EA, JIPP PH, LEFEBVRE PA, NEGREIROS GH, SILVA E, STONE T, TRUMBORE SA AND VIEIRA S. 1994. The role of deep roots in the hydrological and carbon cycles of Amazonian forests and pastures. Nature 372: 666-669.

OLIVEIRA GQ, LOPES AS, JUNG LH, NAGEL PL AND BERTIOLI DM. 2011. Desempenho de métodos de estimativa da evapotranspiração de referência baseadas na temperatura do ar, em Aquidauana-MS. Rev Bras Agric Irr 5: 224-234.

PANDEY K, DABRAL PP AND PANDEY V. 2016. Evaluation of reference evapotranspiration methods for the northeastern region of India. ISWCR 4: 52-63.

PANDEY V, PANDEY PK AND MAHANTA AP. 2014. Calibration and performance verification of HargreavesSamani equation in a humid region. J Irrig Drain Eng 63: 659-667.

PEREIRA AR, ANGELOCCI LR AND SENTELHAS PC. 2002. Agrometeorologia, fundamentos e aplicações práticas. Guaíba: Agropecuária.

PEREIRA AR, VILLA NOVA NA AND SEDIYAMA GC. 1997. Evapo(transpi)ração. Piracicaba: Fealq.

PEREIRA DR, YANAGI SNM, MELLO CR, SILVAAM AND SILVA LA. 2009. Desempenho de métodos de estimativa da evapotranspiração de referência para a região da Serra da Mantiqueira, MG. Cienc Rural 39: 2488-2493.

PEREIRA LS, ALLEN RG, SMITH M AND RAES D. 2015. Crop evapotranspiration estimation with FAO56: Pastland future. Agric Water Manage 147: 4-20

PRIESTLEY CHB AND TAYLOR RJ. 1972. On the assessment of the surface heat flux and evaporation using large-scale parameters. Mon Weather Rev 100: 81-92.

ROADS J, KANAMITSU M AND STEWART R. 2002. Water and energy budgets in the NCEP-DOE reanalyses. J Hydrometeorol 3: 227-248.
ROERINK GJ, SU Z AND MENENTI M. 2000. S - SEBI: A Simple Remote Sensing Algorithm to Estimate the Surface Energy Balance. Phys Chem Earth Pt B 25: 147-157.

SENTELHAS PC, GILLESPIE TJ AND SANTOS EA. 2010. Evaluation of FAO Penman-Monteith and alternative methods for estimating reference evapotranspiration with missing data in Southern Ontario, Canada. Agric Water Manage 97: 635-644.

SHUTTLEWORTH WJ. 1988. Evaporation from Amazonian Rainforest. P Roy Soc Lond B Bio 233: 321-346.

SILVA JÚNIOR RO, QUEIROZ JCB, FERREIRA DBS, TAVARES AL, SOUZA-FILHO PWM, GUIMARÃES JTF AND ROCHA EJP. IN PRESS. Estimativa de precipitação e vazões médias para a bacia hidrográfica do rio Itacaiúnas (BHRI) - Amazônia Oriental - Brasil. RBGF 10(5).

SOARES AK ET AL. 2003. Análise do balanço hídrico serial na bacia da represa do Broa, SP. In: Simpósio Brasileiro de Recursos Hídricos, 15, Curitiba: ABRH.

SOMMER R, SA TDDA, VIELHAUER K, ARAUJO ACD, FOLSTER H AND VLEK PLG. 2002. Transpiration and canopy conductance of secondary vegetation in the eastern Amazon. Agric Forest Meteorol 112: 103-121.

SOUSA AML, COLLISCHONN W AND SILVA RBC. 2007. Estimativa da evapotranspiração real derivada do sensor MODIS: aplicação no leste da Amazônia. In: Simpósio de Recursos Hídricos Sul-Sudeste, p. 1-19.

SOUSA IF, SILVA, VPR DA, SABIN FG, NETTO AOA, SILVA BKN AND AZEVEDO PV DE. 2010. Evapotranspiração de referência nos perímetros irrigados do Estado de Sergipe. R Bras Eng Agríc Ambiental 14: 633-644.

SOUZA FILHO JDC, RIBEIRO A, COSTA MH AND COHEN JP. 2005. Control mechanisms of the seasonal variation of transpiration in a northeast Amazonia tropical rainforest. Acta Amazon 35: 223-229.

SOUZA-FILHO PWM, SOUZA EB, SILVA JÚNIOR RO, NASCIMENTO JÚNIOR WR, MENDONÇA BRV, GUIMARÃES JTF, DALL'AGNOL R AND SIQUEIRA JO. 2016. Four decades of land-cover, landuse and hydroclimatology changes in the Itacaiúnas River watershed, southeastern Amazon. J Environ Manage 167: 175-184.

TABARI H. 2010. Evaluation of reference crop evapotranspiration equations in various climates. Water Resour Manage 24: 2311-2337.

TABARI H, GRISMER ME AND TRAJKOVIC S. 2013. Comparative Analysis of 31 references evapotranspiration methods under humid conditions. Irrig Sci 31: 107-117.

TEMESGEN B, ECHING S, DAVIDOFF B AND FRAME K. 2005. Comparison of some reference evapotranspiration equations for California. J Irrig Drain Eng 131: 73-84. 
THORNTHWAITE CW. 1948. An approach toward a rational classification of climate. Geogr Rev 38: 55-94.

TURC L. 1961. Estimation of irrigation water requirements, potential evapotranspiration: A simple climatic formula evolved up to date. Ann Agron 12: 13-49.

VON RANDOW RCS, VON RANDOW C, HUTJES RWA, TOMASELLAJAND KRUIJTB. 2011. Evapotranspiration of deforested areas in central and southwestern Amazonia. Theor Appl Climatol 109: 1-16.

WIDMOSER P. 2009. A discussion on an alternative to Penman-Monteith equation. Agric Water Manage 96: 711721.

WOHL E ET AL. 2012. The hydrology of the humid tropics. Nat Clim Change 2: 655-662.

XAVIER AC, KING CW AND SCANLON BR. 2015. Daily gridded meteorological variables in Brazil (1980-2013). Int. J Climatol 36: 2644-2659.

XU CY AND CHEN D. 2005. Comparison of seven models for estimation of evapotranspiration and groundwater recharge using lysimeter measurement data in Germany. Hydrol Process 19: 3717-3734.
XU CY AND SINGH VP. 2001. Evaluation and generalization of temperature-based methods for calculating evaporation. Hydrol Process 15: 305-319.

XU CY AND SINGH VP. 2002. Cross comparison of empirical equations for calculating potential evapotranspiration with data from Switzerland. Water Resour Manage 16: 197-219.

XU J, PENG S, DING J, WEI Q AND YU Y. 2013. Evaluation and calibration of simple methods for daily reference evapotranspiration estimation in humid East China. Arch Agron Soil Sci 59(6): 845-858.

YODER RE, ODHIAMBO LO AND WRIGHT WC. 2005. Evaluation of methods for estimating daily reference crop evapotranspiration at a site in the humid Southeast United States. Appl Eng Agric 21: 197-202.

ZENG N. 1999. Seasonal cycle and interannual variability in the Amazon hydrologic cycle. J Geophys Res 104: 90979106.

ZHAO L, XIA J, XU CY, WANG Z, SOBKOWIAK L AND LONG C. 2013. Evapotranspiration estimation methods in hydrological models. J Geogr Sci 23: 359-369. 